\title{
Micropropagation of the wild legume Canavalia rosea (Sw.) DC. from coastal sand dunes
}

\author{
MELWYN D'CUNHA and KANDIKERE R. SRIDHAR \\ Department of Biosciences, Mangalore University, Mangalagangotri 574 199, Mangalore, \\ Karnataka, India \\ Corresponding author: Kandikere R. Sridhar, sirikr@yahoo.com
}

(Received on 5 May 2010; Accepted on 17 January 2011)

\begin{abstract}
The wild legume Canavalia rosea (known in India as C. maritima) grows on coastal sand dunes of Southwest India. Anthers and 8 other explant types of this species (tender pods, cotyledons of ripened beans, cotyledons of germinated dry seeds, hypocotyls, young shoot buds, nodes, internodes, and roots) were used for in vitro culture. Among them, cotyledons and hypocotyls of germinated dry seeds showed a positive response. Friable callus production was seen within 4 weeks at the cut ends of cotyledon explants in MS medium fortified with $1 \mathrm{mg} \mathrm{L}^{-1}$ each of BAP and 2iP. Cotyledon explants of seedlings also showed shoot bud induction in MS medium with $0.5 \mathrm{mg} \mathrm{L}^{-1}$ each of BAP and 2iP. Increased shoot bud induction was seen at elevated concentrations of hormones (7-27\%). Hypocotyls inserted upside down on the medium with $1 \mathrm{mg} \mathrm{L}^{-1}$ each of BAP and 2iP, gave rise to leafy shoots within 4 weeks. Solitary or multiple somatic embryos emerged from the 10 week-old calli of cotyledons supplemented with $1.5 \mathrm{mg} \mathrm{L}^{-1}$ each of BAP and 2iP. Secondary embryos were also induced in some of the somatic embryos. Hypocotyls excised from 3-5-day-old seedlings in MS medium at low concentrations of auxins, produced roots within 3 weeks. The stem cuttings treated with IBA $\left(0.25 \mathrm{mg} \mathrm{L}^{-1}\right)$ increased the percentage of rooting response. Conventional methods of propagation of $C$. rosea through seeds may fail due to seed dormancy and mortality of the seedlings under the hostile conditions of coastal sand dunes, thus in vitro and ex vitro culture and hardening techniques may be feasible for rehabilitation. Moreover, such cultured tissues may serve for extraction of secondary metabolites.
\end{abstract}

Keywords: wild legume, Canavalia rosea, coastal sand dunes, in vitro propagation, ex vitro culture

\section{INTRODUCTION}

Tropical coastal sand dunes (CSDs) are endowed with a variety of plants of the families Asteraceae, Cyperaceae, Fabaceae, and Poaceae (Moreno-CASAsola 1988; Rao \& SheriefF 2002; Sridhar \& Bhagya 2007; Celsi \& Monserrat 2008). On CSDs of the Indian subcontinent, species belonging to the family Fabaceae outnumber other families (SRIDHAR \& BHAGYA 2007). Leguminous plants of this family found on CSDs are economically valuable as food, fodder, fertilizer, bioactive compounds, 
and pharmaceuticals (Sridhar \& BhagYa 2007; Pattanaik et al. 2008). Besides, they are valuable to coastal dwellers, based on traditional uses. Among the Fabaceae on Indian CSDs, the perennial creepers Canavalia rosea and C. cathartica are dominant sand binders associated with rhizobia, endophytic fungi, and arbuscular mycorrhizal fungi (Chen et al. 2000; Seena \& SRidhar 2004, 2006; Arun \& Sridhar 2004).

The natural forces influencing CSD vegetation mainly include sea level changes, storms, sand movements, and climatic changes (e.g. global warming). Human interference, such as industrialization, pollution, waste disposal, sand mining, commercial forestry, and beach tourism, causes destabilization of CSD ecosystems. The natural vegetation of the southwest CSDs of India is diminishing due to human interference (e.g. sand mining, beach recreation, and clearing vegetation by fire). The pantropical plant Canavalia rosea (Sw.) DC. [synonyms: C. lineata (Thunb.) DC.; C. obtusifolia (Lam.) DC.; C. maritima Thouars; Dolichos maritimus Aublet; D. obtusifolius Lam.; D. roseus $\mathrm{Sw}$.] on the southwest coast of India is used as green manure, source of nutrition, and pharmaceuticals (SEena \& SRidhar 2006; Sridhar \& Bhagya 2007; BHAGYA \& SRIDHAR 2009). In spite of natural and human interference, C. rosea regenerates on the CSDs of the southwest coast of India probably due to seed dormancy (ARUN et al. 2001). An alternative method of regeneration of the endangered C. rosea for future benefit is tissue culture. The current study aimed to investigate the regeneration potential of C. rosea in vitro and ex vitro, with a view of its use in micropropagation and production of pharmaceutically valuable substances.

\section{MATERIALS AND METHODS}

\section{Explants for in vitro study}

Dry seeds, tender pods, and ripened beans of C. rosea were collected during post-monsoon and summer seasons (December 2006 - May 2007) from the CSDs of Someshwara $\left(12^{\circ} 47^{\prime} \mathrm{N}, 74^{\circ} 52^{\prime} \mathrm{E}\right)$ on the southwest coast of India. The dry seeds were mechanically scarified and allowed to germinate on a moist sand bed for up to 72 $120 \mathrm{~h}$. Tender pods, cotyledons of ripened beans, cotyledons of germinated dry seeds, and hypocotyls, were used as explants for in vitro culture. Young shoot buds, nodes, internodes, and roots were also employed as explants. They were washed in running water for 20-30 min, to eliminate extraneous matter, and surface-sterilized with $0.2 \%$ $(w / v)$ Bavistin (carbendazim) (Northern Minerals Ltd., Mumbai) for $10 \mathrm{~min} ; 0.1 \%$ $(\mathrm{w} / \mathrm{v})$ mercuric chloride (Qualigens, India) for $7 \mathrm{~min}$; and $0.1 \%(\mathrm{w} / \mathrm{v})$ sodium lauryl sulphate (Qualigens, India) for $7 \mathrm{~min}$. Next, the plant material was rinsed in sterile distilled water 3-5 times, to eliminate the traces, and excised into desired size aseptically. Anthers from flower buds were also selected as explants.

\section{Nutrient medium}

The MS medium (Murashige \& Skoog 1962) was prepared by using analytical grade ingredients (macronutrients, micronutrients, agar, sucrose) (Hi-Media Laboratories, India; Merck, India) and sterile double-distilled water. The medium was supplemented with plant growth regulators (PGRs): 6-benzyl amino purine (BAP), 6 - $\gamma, \gamma$-dimethylallylaminopurine (2iP), $\alpha$-naphthaleneacetic acid (NAA), 2,4-dichlo- 
rophenoxy acetic acid (2,4-D), indole acetic acid (IAA), indole butyric acid (IBA), and kinetin (KIN). Moreover, vitamins (pyridoxine $\mathrm{HCl}$, thiamine $\mathrm{HCl}$, nicotinic acid) and glycine (Sigma Aldrich, USA) were incorporated into the medium. Stock solutions (of macronutrients, micronutrients, vitamins, glycine, and PGRs) were prepared using sterile double-distilled water. The PGRs were weighed and dissolved in a few drops of $\mathrm{NaOH}$ or ethanol, before making up to the desired volume. The stock solutions of ingredients for the medium were preserved at $4^{\circ} \mathrm{C}$ in a refrigerator until use. The stock solutions were checked for turbidity and precipitation before preparing the medium, to avoid contamination. The basal medium was prepared using a required amount of stock solutions, sucrose, and myo-inositol in a beaker containing $250 \mathrm{~mL}$ of doubledistilled water, mixed, and diluted up to $950 \mathrm{~mL}$. Medium $\mathrm{pH}$ was set to $5.7 \pm 0.1$ on mixing, and the volume was made up to $1000 \mathrm{~mL}$. To this basal medium, required quantities of PGRs and agar were transferred, melted in a microwave oven, dispensed into culture vials (Borosil, India), and autoclaved at $1.05 \mathrm{~kg} / \mathrm{cm}^{2}$ for $20 \mathrm{~min}$. Anthers were aseptically cultured in Nitsch medium (NITSCH 1969) with BAP and 2,4-D.

\section{Explant transfer and incubation}

The sterilized explants were transferred to culture vials aseptically by using a laminar flow workbench (Klenzaids, India). A single explant was transferred to each culture tube, while 4-5 into conical flasks. All culture vials were incubated at uniform humidity $(75 \pm 5 \%)$ and temperature $\left(25 \pm 2^{\circ} \mathrm{C}\right)$ with cool daylight fluorescent tubes $\left(10-15 \mu \mathrm{E} / \mathrm{m}^{-2} / \mathrm{s}^{-1}, 16-\mathrm{h}\right.$ photoperiod monitored by luxmeter) (Voltkraft MS 1500 , Germany).

\section{Ex vitro experiments}

For ex vitro study, juvenile shoots with $2-3$ nodes $(0.2-0.4 \mathrm{~cm} \times 20-30 \mathrm{~cm})$ were collected from the CSDs of Someshwara, and juvenile vines of one-year-old plants raised in the greenhouse were also used. The shoots were excised into 15$\mathrm{cm}$ segments, and the lower end (internodal region) was cut obliquely. Forty shoot segments of each plant were rinsed in running tap water to remove the extraneous matter. The obliquely cut ends were immersed in vials containing different concentrations of IBA and NAA (0-7.5 $\left.\mathrm{mg} \mathrm{L}^{-1}\right)$ for $30 \mathrm{~min}$. The hormone-treated shoots were next blotted and transferred to polythene bags containing a mixture of sand, soil, and vermiculite (1:2:1). The segments without hormone treatment served as a control. The planted shoots were maintained under shade $\left(28 \pm 2^{\circ} \mathrm{C}\right.$; humidity $\left.70-80 \%\right)$. They were sprayed with water regularly, but excess watering was avoided to prevent water logging and decay of stems. The rooting response (number of roots per plant and root length) of each cutting was assessed after 3 weeks. The second set of shoots was treated with different doses of auxins (IBA and NAA), similarly as pulse treatment (duration: 15, 30, 60, and $120 \mathrm{~min}$ ), and the response of shoots was assessed.

\section{RESULTS}

Among the shoot buds, nodes, internodes, roots, tender pods, cotyledons of ripened beans, cotyledons of germinated dry seeds, hypocotyls, and anthers used for in 
vitro culturing, shoot buds, internodes, cotyledons of germinated dry seeds and hypocotyls responded positively. Anthers cultured in Nitsch medium did not show any morphogenetically differentiated structures.

\section{Callus and shoot bud induction}

Numbers of cotyledon explants of dry seeds used for culturing ranged between 30 and 42 (Table 1). Callus was induced at the cut end of the cotyledons (Fig. 1a), while the intact portion failed to produce callus, although enlarged. Callus induction rate $(93 \%)$, as well as the amount of callus, was highest at $1 \mathrm{mg} \mathrm{L}^{-1}$ each of BAP and $2 \mathrm{iP}$, while lowest $(10 \%)$ at $2 \mathrm{mg} \mathrm{L}^{-1}$ each of BAP and 2iP. Many brown-coloured calli responded positively, by turning into light green primordial structures (Fig. 1a). The calli produced by cotyledon explants were friable. There was no callus formation in

Table 1. Callus induction in dry seed cotyledon explants of Canavalia rosea in MS medium supplemented with BAP and 2iP after 4 weeks of culture

\begin{tabular}{|c|c|c|c|c|c|}
\hline \multicolumn{2}{|c|}{ PGR $\left(\mathrm{mg} \mathrm{L}^{-1}\right)$} & \multirow{2}{*}{$\begin{array}{r}\text { Number of } \\
\text { explants }\end{array}$} & \multirow{2}{*}{$\begin{array}{l}\text { Number of explants } \\
\text { forming callus }\end{array}$} & \multirow[t]{2}{*}{ Callus induction (\%) } & \multirow{2}{*}{$\begin{array}{r}\text { Amount of } \\
\text { callus }^{\mathrm{a}}\end{array}$} \\
\hline BAP & $2 \mathrm{iP}$ & & & & \\
\hline 0 & 0 & 30 & 7 & 23.3 & + \\
\hline 1.0 & 0 & 42 & 16 & 38.1 & + \\
\hline 2.0 & 0 & 40 & 4 & 10.0 & + \\
\hline 0.5 & 0.5 & 30 & 22 & 73.3 & ++ \\
\hline 1.0 & 1.0 & 30 & 28 & 93.3 & +++ \\
\hline 1.5 & 1.5 & 30 & 27 & 90.0 & +++ \\
\hline
\end{tabular}

${ }^{\text {a }}$, small; ++, moderate; +++ , large.

Table 2. Shoot bud induction in germinated seed cotyledon explants of Canavalia rosea in MS medium supplemented with BAP and 2iP after 4 weeks of culture

\begin{tabular}{rrrrr}
\hline \multicolumn{2}{r}{ PGR $\left(\mathrm{mg} \mathrm{L}^{-1}\right)$} & $\begin{array}{r}\text { Number of } \\
\text { explants }\end{array}$ & $\begin{array}{r}\text { Number of explants } \\
\text { forming shoot buds }\end{array}$ & $\begin{array}{r}\text { Shoot bud } \\
\text { induction (\%) }\end{array}$ \\
\cline { 2 - 2 } & $2 \mathrm{iP}$ & 30 & 0 & 0 \\
0 & 0 & 42 & 0 & 0 \\
1.0 & 0 & 40 & 0 & 0 \\
2.0 & 0.0 & 30 & 2 & 6.7 \\
0.5 & 0.5 & 30 & 5 & 16.7 \\
1.0 & 1.0 & 30 & 8 & 26.7 \\
1.5 & 1.5 & & 8 & 0.7 \\
\hline
\end{tabular}



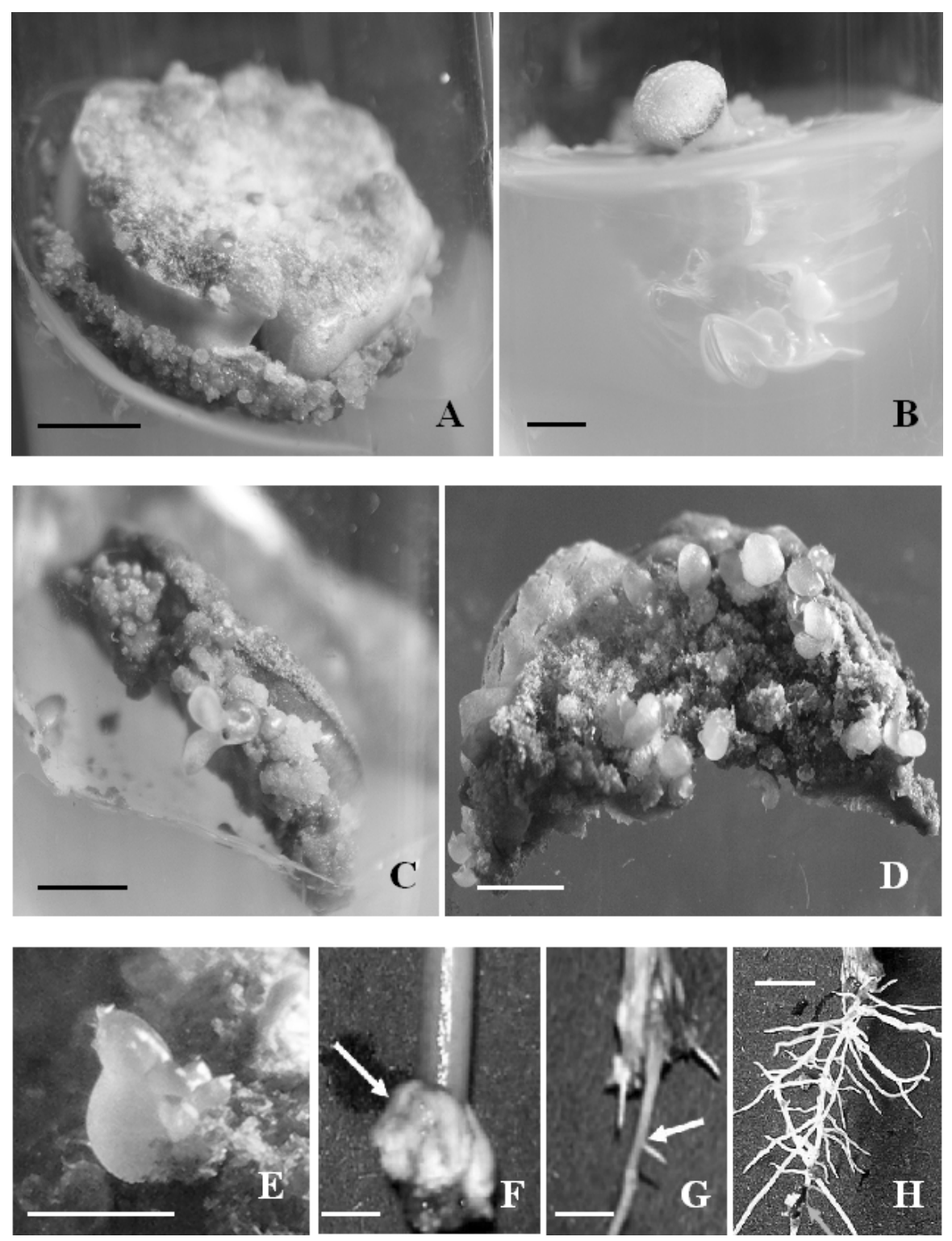

Fig. 1. Tissue induction in Canavalia rosea: (a) shoot induction in cotyledon explants in MS medium with $0.5 \mathrm{mg} \mathrm{L}^{-1} \mathrm{BAP}$ and 2iP; (b) shoot induction in hypocotyl explants inserted upside down in MS medium with $1 \mathrm{mg} \mathrm{L}^{-1} \mathrm{BAP}$ and 2iP; (c) somatic embryogenesis in cotyledon explants in MS medium with $1.5 \mathrm{mg} \mathrm{L}^{-1} \mathrm{BAP}$ and 2iP; (d) multiple somatic embryogenesis in cotyledon explants in MS medium with $1 \mathrm{mg} \mathrm{L}^{-1} \mathrm{BAP}$ and 2iP; (e) induction of secondary embryos in cotyledon explants in MS medium with $1.5 \mathrm{mg} \mathrm{L}^{-1} \mathrm{BAP}$ and $2 \mathrm{iP}$; (f) callus (arrow) formation at the cut end of a shoot after pulse treatment with $0.25 \mathrm{mg} \mathrm{L}^{-1} \mathrm{IBA}$; (g) root induction (arrow) in a shoot after pulse treatment with $0.25 \mathrm{mg} \mathrm{L}^{-1} \mathrm{IBA}$; (h) spherical structures formed in ex-vitro-produced roots (arrow) after pulse treatment with $1 \mathrm{mg} \mathrm{L}^{-1}$ NAA for $120 \mathrm{~min}$ (Scale bar: $5 \mathrm{~mm}$ ) 
hypocotyls with different concentrations of PGRs in 4 weeks, although they enlarged and remained green.

Cotyledon explants of seedlings at a lower concentration of hormones $\left(0.5 \mathrm{mg} \mathrm{L}^{-1}\right.$ each of BAP and $2 \mathrm{iP}$ ) gave rise to tiny green shoots at both the distal and proximal ends (Fig. 1a). Increased concentrations of hormones caused a progressive increase in shoot bud induction (from $7 \%$ to $27 \%$ ) (Table 2). At $1 \mathrm{mg} \mathrm{L}^{-1}$ each of BAP and 2iP, shoots emerged from proximal, middle, and distal parts of cotyledon explants. The hypocotyls inserted upright on the medium, although remained green and enlarged, failed to produce leafy shoots. However, up to $10 \%$ of the hypocotyls inserted upside down on the medium at $1 \mathrm{mg} \mathrm{L}^{-1}$ each of BAP and 2iP, gave rise to leafy shoots (Fig. 1b). Hypocotyl explants at other concentrations of hormones expanded and remained green, but failed to produce shoots for up to 4 weeks. Up to $8 \%$ stem internodes showed callus formation in the basal medium.

\section{Embryogenesis and rooting}

Solitary or multiple somatic embryos (Fig. 1c, d) emerged within 10 weeks from dry seed cotyledon calli (Table 3). The frequency of emergence of somatic embryos was higher (27\%) in MS medium supplemented with $1.5 \mathrm{mg} \mathrm{L}^{-1}$ each of BAP and 2iP. Even with senescence of the mother tissue, the somatic embryos continued to survive (Fig. 1c). In some somatic embryos, secondary embryos were induced (Fig. 1e). Solitary and multiple embryos transferred to MS medium with auxins failed to produce shoots and roots due to contamination. None of the hypocotyl explants produced somatic embryos at the various concentrations of hormones.

Table 3. Somatic embryogenesis from dry seed cotyledon callus of Canavalia rosea on MS medium supplemented with BAP and 2iP after 10 weeks of culture

\begin{tabular}{crrrr}
\hline PGR $\left(\mathrm{mg} \mathrm{L}^{-1}\right)$ & & $\begin{array}{r}\text { Number of } \\
\text { explants }\end{array}$ & $\begin{array}{r}\text { Number of explants } \\
\text { forming embryos }\end{array}$ & $\begin{array}{r}\text { Somatic embryo } \\
\text { induction }(\%)\end{array}$ \\
\hline BAP & $2 \mathrm{iP}$ & 30 & 0 & 0 \\
1.0 & 0 & 42 & 0 & 0 \\
2.0 & 0 & 40 & 0 & 0 \\
0.5 & 0 & 30 & 1 & 3.3 \\
1.0 & 1.0 & 30 & 3 & 10.0 \\
1.5 & 1.5 & 30 & 8 & 26.7 \\
\hline
\end{tabular}

The hypocotyls excised from 3-5-day-old seedlings responded positively to rooting on MS medium at low concentrations of BAP, IAA and $\mathrm{KIN}(0,0.5$ and $1 \mathrm{mg}$ $\left.\mathrm{L}^{-1}\right)$. In the basal medium, $20 \%$ of the hypocotyls gave rise to 3 roots within 3 weeks (length $1.5-4 \mathrm{~cm}$ ). In hypocotyls, up to $10 \%$ root initiation was seen in the medium 
Table 4. Ex vitro rooting of stem segments of Canavalia rosea treated with IBA for 30 min (mean $\pm \mathrm{SE})$

\begin{tabular}{cccc}
\hline $\begin{array}{c}\text { IBA } \\
\left(\mathrm{mg} \mathrm{L}^{-1}\right)\end{array}$ & Rooting* $^{\text {Mean number of }}$ & $\begin{array}{c}\text { Mean root length } \\
(\mathrm{cm})\end{array}$ \\
\hline 0 & 16 & $5.50 \pm 0.39(N=16)$ & $4.10 \pm 0.18(N=88)$ \\
0.25 & 20 & $2.55 \pm 0.35(N=20)$ & $1.95 \pm 0.24(N=51)$ \\
0.50 & 16 & $3.75 \pm 0.76(N=16)$ & $2.48 \pm 0.13(N=60)$ \\
1.00 & 12 & $1.33 \pm 0.14(N=12)$ & $0.40 \pm 0.09(N=16)$ \\
2.50 & 17 & $1.41 \pm 0.43(N=17)$ & $0.75 \pm 0.15(N=24)$ \\
5.00 & 15 & $1.60 \pm 0.14(N=15)$ & $0.36 \pm 0.04(N=24)$ \\
7.50 & 0 & 0 & 0 \\
\hline
\end{tabular}

* The initial number of segments was 40 .

supplemented with $0.5 \mathrm{mg} \mathrm{L}^{-1}$ each of BAP, IAA and KIN, and with $1 \mathrm{mg} \mathrm{L}^{-1}$ each of BAP, IAA and KIN resulted in 4 roots. Shoot meristem explants produced roots up to $29 \%$ and resulted in further growth of shoots with leaf formation.

\section{Rooting ex vitro}

Treatment of the stem cuttings of $C$. rosea with IBA at $0.25 \mathrm{mg} \mathrm{L}^{-1}$ for up to $30 \mathrm{~min}$ increased the rooting response (Table 4), but an increased concentration reduced the rooting response. Optimum rooting response of stem cuttings was seen with NAA at $1 \mathrm{mg} \mathrm{L}^{-1}$ for up to $30 \mathrm{~min}$ (Table 5). In pulse treatment, maximum root induction was seen in shoots treated with $0.25 \mathrm{mg} \mathrm{L}^{-1} \mathrm{IBA}$ for $60 \mathrm{~min}$, while it was

Table 5. Ex vitro rooting of stem segments of Canavalia rosea treated with NAA for 30 min (mean $\pm \mathrm{SE})$

\begin{tabular}{rrll}
\hline $\begin{array}{c}\text { NAA } \\
\left(\mathrm{mg} \mathrm{L}^{-1}\right)\end{array}$ & Rooting* & $\begin{array}{c}\text { Mean number of } \\
\text { roots/plant }\end{array}$ & $\begin{array}{c}\text { Mean root length } \\
(\mathrm{cm})\end{array}$ \\
\hline 0 & 16 & $5.44 \pm 0.39(N=16)$ & $4.10 \pm 0.18(N=87)$ \\
0.25 & 7 & $2.00 \pm 0.00(N=7)$ & $1.05 \pm 0.12(N=14)$ \\
0.50 & 16 & $2.50 \pm 0.13(N=16)$ & $0.24 \pm 0.01(N=40)$ \\
1.00 & 31 & $1.77 \pm 0.15(N=31)$ & $0.87 \pm 0.37(N=55)$ \\
2.50 & 24 & $1.33 \pm 0.10(N=24)$ & $1.20 \pm 0.75(N=32)$ \\
5.00 & 24 & $2.29 \pm 0.20(N=24)$ & $3.14 \pm 0.15(N=55)$ \\
7.50 & 23 & $5.65 \pm 1.38(N=23)$ & $4.74 \pm 0.15(N=130)$ \\
\hline
\end{tabular}

* The initial number of segments was 40 . 
maximum after $120 \mathrm{~min}$ treatment with $1 \mathrm{mg} \mathrm{L}^{-1} \mathrm{NAA}$ (Table 6). Compact callus-like structure was formed before root development (Fig. 1f, g), and in some roots (with NAA for $120 \mathrm{~min}$ ) spherical structures were formed (Fig. 1h).

Table 6. Ex vitro rooting of stem segments of Canavalia rosea on pulse treatment with IBA and $\mathrm{NAA}($ mean $\pm \mathrm{SE})$

\begin{tabular}{ccccc}
\hline $\begin{array}{c}\text { Concentration } \\
\left(\mathrm{mg} \mathrm{L}^{-1}\right)\end{array}$ & $\begin{array}{c}\text { Pulse treatment } \\
(\mathrm{min})\end{array}$ & Rooting* & $\begin{array}{c}\text { Mean number of } \\
\text { roots/plant }\end{array}$ & $\begin{array}{c}\text { Mean root length } \\
(\mathrm{cm})\end{array}$ \\
\hline Control & 0 & 15 & $5.73 \pm 0.10(N=15)$ & $4.05 \pm 0.02(N=86)$ \\
0.25 (IBA) & 15 & 20 & $2.80 \pm 0.64(N=20)$ & $1.60 \pm 0.30(N=56)$ \\
& 30 & 20 & $2.60 \pm 0.39(N=20)$ & $1.93 \pm 0.24(N=52)$ \\
& 60 & 24 & $4.33 \pm 0.52(N=24)$ & $3.00 \pm 0.22(N=104)$ \\
& 120 & 23 & $4.52 \pm 0.84(N=23)$ & $1.95 \pm 0.22(N=104)$ \\
& 15 & 32 & $1.06 \pm 0.13(N=32)$ & $1.79 \pm 0.17(N=34)$ \\
& 30 & 32 & $1.75 \pm 0.15(N=32)$ & $0.87 \pm 0.15(N=56)$ \\
& 60 & 31 & $2.06 \pm 0.00(N=31)$ & $1.29 \pm 0.15(N=64)$ \\
& 120 & 32 & $4.00 \pm 0.55(N=32)$ & $1.25 \pm 0.07(N=128)$ \\
\hline
\end{tabular}

* The initial number of segments was 40 .

\section{DISCUSSION}

Plant tissue culture is an innovative method of in vitro multiplication of endangered and economically important plants (PatTNAiK \& Chand 1996). Nickell (1956) initiated studies on in vitro culture of legumes for the first time and thereafter tissue culture techniques have been employed to propagate many legumes. However, the recalcitrant nature of legume tissues has been a major obstacle in developing desired protocols for in vitro regeneration and transformation (DAVEY et al. 1994; KATHIRAVAN et al. 2001). A number of factors are responsible for difficulty in regeneration of legumes (e.g. type of explant, concentration and combination of PGRs, and medium of choice and culture conditions). There are several possibilities of stimulating in vitro caulogenesis and rhizogenesis using species-specific regeneration parameters (e.g. explant source, genotype, and media constituents) (PARROTT et al. 1989). Although multiplication of some legumes cannot be achieved by tissue culture, there is ample scope to induce callus or roots from a variety of explants used for in vitro and ex vitro culture to stimulate and extract valuable metabolites (VANISREE et al. 2004; EKANAYAKE et al. 2007).

Micropropagation of sand dune plants offers advantages to produce disease-free plants having superior growth, disease-resistance, and stress-tolerance for rehabilita- 
tion purposes (GARTON \& Moses 1985; KANE et al. 1989). Information available on the micropropagation of coastal sand dune plant species is relatively scanty (e.g. STRAUB et al. 1988; CoOK et al. 1989; KANE et al. 1993; SRIDHAR 2009). KANE et al. (1993) have developed a protocol for micropropagation of the coastal sand dune creeper Ipomoea pes-caprae (Convolvulaceae) and indicated a potential to propagate up to 446000 plants from a single nodal segment per annum. CooK et al. (1989) attempted regeneration of seashore mallow (Kosteletzkya virginica; Malvaceae) employing callus cultures. Isolation of protoplasts was successful in field-grown plants of Ammophila arenaria (Poaceae) and Cakile maritima (Brassicaceae) (BALESTRI et al. 2001).

Tissue culture studies on Canavalia spp. have been reported by a few investigators (e.g. Hwang et al. 1991, 1996a, b; Ozaki 1993; Kathiravan \& Ignacimuthu 1999; Da Silva et al. 2005). Leaf callus was established from $C$. lineata, and the induced callus gave rise to chlorophyll in the presence of BAP and IAA on exposure to continuous light (HwANG et al. 1991, 1996a). OzAKI (1993) obtained plantlets of C. gladiata from the primary leaf callus in MS medium with NAA and BAP. KATHIRAVAN and IGNACIMUTHU (1999) obtained multiple shoots from nodal explants (with BAP, KIN, and gibberellic acid $\mathrm{GA}_{3}$ ) and roots (with IBA) in C. virosa in MS medium. Cotyledon callus of $C$. brasiliensis was induced in MS medium supplemented with 2,4-D and KIN (DA Silva et al. 2005).

Canavalia rosea is widespread across pantropical coastal sand dunes. As the seeds of $C$. rosea have a high protein content, several essential amino acids, and medicinal properties, they may serve as future primary source of nutrition and health benefits of coastal dwellers (Sridhar \& SEena 2006; SEena \& SRidhar 2006; SRidhar \& Bhagya 2007; Bhagya \& Sridhar 2009). So far, studies on in vitro regeneration or vegetative propagation of $C$. rosea have not been attempted. In the present study, explants of tender pods and cotyledons of ripened beans of $C$. rosea did not respond positively in callus development, but the cotyledons of germinated dry seeds and hypocotyls produced calli. Among the PGRs supplemented, BAP and 2iP promoted callus formation. The current study clearly shows the morphogenetic potential of cotyledon explants of $C$. rosea and the possibility of induction of somatic embryogenesis directly from the induced calli. Both the white and green calli of cotyledons produced shoot buds and somatic embryos. Induction of somatic embryogenesis from cotyledon explants would overcome many constraints faced during zygotic embryo germination due to seed dormancy. DA SiLVA et al. (2005) used cotyledon explants of C. brasiliensis to induce callus in MS medium supplemented with 2,4-D and KIN, and they were successful in obtaining callus within 4 weeks. In our study, also callus formation in cotyledon explants of $C$. rosea was achieved within 3-4 weeks at various concentrations of BAP and $2 \mathrm{iP}$. However, callus induction by IAA and KIN was relatively poor $(\sim 10 \%)$. Therefore, it is necessary to optimize regeneration of somatic embryos for successful genetic transformation. Embryogenesis, solitary shoot, and multiple shoot induction by the cotyledon callus and root generation in hypocotyl cultures of $C$. rosea are positive signs of successful micropropagation through in vitro culture. Although simultaneous shoot and root induction was not successful in calli of cotyledon explants, the calli were friable, indicating its usefulness in suspension cultures for production of secondary metabolites. 
Although $C$. rosea and C. cathartica share the same ecological niche (coastal sand dunes) in pantropical regions, their explants showed differential properties during in vitro and ex vitro culture. Unlike in cotyledons of $C$. cathartica, in C. rosea an increase in BAP and 2iP concentrations elevated the percentage of callus induction as well as the quantity of callus (D'CunHA \& SRIDHAR 2011). The low dose of BAP $\left(1 \mathrm{mg} \mathrm{L}^{-1}\right)$ without $2 \mathrm{iP}$ served as a hormetic dose in C. cathartica in elevating the callus induction rate and callus production by cotyledon explants. Similarly, unlike in $C$. cathartica, shoot bud induction and somatic embryogenesis in cotyledons of C. rosea were also elevated by increasing the concentrations of BAP and $2 \mathrm{iP}$. In ex vitro rooting of stems, IBA has not elevated the number of roots per plant and root length in C. rosea, but IBA at $2.5 \mathrm{mg} \mathrm{L}^{-1}$ elevated the number of roots and root length in C. cathartica.

Seed germination is usually low in C. rosea due to dormancy. Thus, ex vitro propagation of shoot segments will be advantageous to meet the local requirements to rehabilitate and revegetate coastal regions, aiming to enrich and stabilize the soil. The ex vitro methods of plant regeneration are economical and less time-consuming. Shoot explants obtained from the field or the greenhouse responded positively to pulse treatment with auxins. The ex vitro rooting and propagation of $C$. rosea have many advantages over in vitro methods by circumventing the problem of contamination or loss of cultures.

Tissue culture is an important tool to study the biosynthesis of concanavalin A (con A) (SATo et al. 1993). In C. ensiformis, embryos and cotyledons cultured for 90 days contain con A. Con A-like lectin was also detected in large quantities in tissues of cotyledons and embryos of C. gladiata, while it was in small quantities in epicotyls and hypocotyls (GHosh et al. 1985). Tissue cultures established from embryos and cotyledons of $C$. virosa contain lectin (JAYAVARDHANAn et al. 1996). Stems and leaves of plantlets derived from embryos of $C$. virosa also contain lectin, but the roots are devoid of it. Callus derived from immature cotyledons of $C$. virosa exhibited the largest concentration of lectin. Canavanine and canaline were detected in the green callus of $C$. lineata (HwANG et al. 1996a). Biosynthesis of canavanine was higher in in-vitro-propagated leaves of $C$. lineata than in roots (HwANG et al. 1996b). In vitro callus cultures derived from hypocotyls of $C$. ensiformis showed 5-fold accumulation of canavanine between days 5 and 10 (RAmírez et al. 1992). HwANG et al. (1996a) demonstrated an increased arginine content in white callus suspension cultures of C. lineata on addition of citrulline, ornithine, and argininosuccinic acid. However, the production of arginine was lower in green callus. Non-embryogenic and nonmorphogenetic types of calli obtained in our study could be potentially useful for the extraction of secondary metabolites. As a first step, it is necessary to investigate various tissues and calli derived from $C$. rosea for quantitative and qualitative assays of secondary metabolites of pharmaceutical importance.

Acknowledgments: We are grateful to Mangalore University for granting a permission to carry out this study at the Department of Biosciences under University Grants Commission Faculty Improvement Programme. MDC is grateful to the Principal and Fr. Leo D'Souza, Director, Applied Biology, St. Aloysius College, Mangalore, for support. 


\section{REFERENCES}

Arun A. B., SRidHAR K. R. 2004. Symbiotic performance of fast-growing rhizobia isolated from the coastal sand dune legumes of west coast of India. Biol. Fert. Soils 40: 435-439.

Arun A. B., Raviraja N. S., Sridhar K. R. 2001. Effect of temperature, salinity and burial on seed germination and seedling emergence of five coastal sand dune legumes. Int. J. Ecol. Environ. Sci. 27: 23-29.

Balestri E., Luccarini G., Cinelli F. 2001. Isolation of leaf protoplasts from Pancratium maritimum L. and two other dune plants: possible applications. J. Coast. Res. 17: 188-194.

Bhagya B., SRidhar K. R. 2009. Ethnobiology of coastal sand dune legumes of southwest India. Indian J. Trad. Knowl. 9: 611-620.

Celsi C. E., Monserrat A. L. 2008. Vascular plants, coastal dunes between Pehuen-có and Monte Hermoso, Buenos Aires, Argentina. Check List 4: 37-46.

Chen W. -M., Lee T. -M., Lam C. -C., Cheng C. -P. 2000. Characterization of halotolerant rhizobia isolated from root nodules of Canavalia rosea from seaside areas. FEMS Microbiol. Ecol. 34: 9-16.

Cook D. A., Decker D. M., Gallagher J. L. 1989. Regeneration of Kosteletzkya virginica (L.) Presl. (Seashore Mallow) from callus cultures. Plant Cell, Tiss. Org. Cult. 17: 11-19.

Da Silva, Fabia M. B., Moreira R. A., Horta A. C. G., Silva A. L. C. 2005. The lectin content of cotyledonary callus from Canavalia brasiliensis. Asian J. Pl. Sci. 4: 214-219.

Davey M. R., Kumar V., Hammatt N. 1994. In vitro culture of legumes. In: Plant Cell and Tissue Culture (Vasil I. K., Thorpe T. A., Eds), pp. 313-329, Kluwer Academic Publishers, The Netherlands.

D'CunHa M., SRidHAR K. R. 2011. Micropropagation of Canavalia cathartica of coastal sand dunes. J. Agric. Technol. 7: 85-96.

Ekanayake S., Skog K., Asp N. -G. 2007. Canavanine content in sword beans (Canavalia gladiata): Analysis and effect of processing. Food Chem. Toxicol. 45: 797-803.

Garton S., Moses M. 1985. Production of native plants in tissue culture. Combined Proc. Int. Pl. Propagators' Soc. 35: 306-317.

Ghosh B. N., Dasgupta B., Sircar P. K. 1985. Lectin concanavalin A distribution at different stages in the tissues of Canavalia gladiata. Curr. Sci. 54: 80-82.

Hwang I. D., KoH S. C., Kwon Y. M. 1991. Induction and free amino acid analysis of callus from Canavalia lineata leaf. Korean J. Bot. 34: 223-228.

Hwang I. D., KIM S. G., Kwon Y. M. 1996a. Canavanine metabolism in tissue cultures of Canavalia lineata. Plant Cell, Tiss. Org. Cult. 45: 17-23.

Hwang I. D., KIm S. G., Kwon Y. M. 1996b. Canavanine synthesis in the in vitro propagated tissues of Canavalia lineata. Pl. Cell Rep. 16: 180-183.

Jayavardhanan K. K., PadikKala K., PanikKar K. R. 1996. Lectin synthesis in callus culture established from seeds of Canavalia virosa. Biol. Plant. 38: 329-334.

Kane M. E., Sheehan T. J., Dehgan B., Philman N. L. 1989. In vitro propagation of Florida native plants. Proc. Florida St. Hort. Soc. 102: 264-268.

Kane M. E., Bird K. T., LeE T. M. 1993. In vitro propagation of Ipomoea pes-caprae (railroadvine). J. Coast. Res. 9: 356-362.

Kathiravan K., Ignacimuthu S. 1999. Micropropagation of Canavalia virosa (Roxb.) Wight \& Arn. A medicinal plant. Phytomorphology 49: 61-66.

Kathiravan K., Sheshadri S., Prakash S., Ignacimuthu S. 2001. Biotechnological applications in grain legume improvement: A critical review. Pl. Cell Biotechnol. Mol. Biol. 2: 1-18.

Moreno-Casasola P. 1988 Patterns of plant species distribution on coastal dunes along the Gulf of Mexico. J. Biogeogr. 15: 787-806.

Murashige T., Skoog F. 1962. A revised medium for rapid growth and bioassays with tobacco tissue cultures. Physiol. Plant. 15: 473-497. 
Nickell L. G. 1956. The continuous submerged cultivation of plant tissue as single cells. Proc. Nat. Acad. Sci. 42: 848-850.

Nitsch J. P. 1969. Experimental androgenssis in Nicotiana. Phytomorphology 19: 389-404.

OzAKI K. 1993. Plantlet Formation from the Callus of Primary Leaf in Sword Bean [Canavalia gladiata (Jacq.) DC.]. Pl. Tiss. Cult. Lett. 10: 45-48.

Parrott W. A., Williams E. G., Hildebrand D. F., Collins G. B., Williams E. G. 1989. Effect of genotype on somatic embryogenesis from immature cotyledons of soybean. Plant Cell, Tiss. Org. Cult. 16: 15-21.

Pattnaik S. K., Chand P. K. 1996. In vitro propagation of the medicinal herbs Ocimum americanum L. syn. O. canum Sims (hoary basil) and Ocimum sanctum (holy basil). Pl. Cell Rep. 15: 846-850.

Pattanaik C., Reddy C. S., Dhal N. K. 2008. Phytomedicinal study of coastal sand dune species of Orissa. Ind. J. Trad. Know. 7: 263-268

Ramírez M., Alpizar L., Quiroz J., Oropeza C. 1992. Formation of L-canavanine in vitro culture of Canavalia ensiformis (L.) DC. Plant Cell, Tiss. Org. Cult. 30: 231-235.

Rao T. A., Sherieff A. N. 2002. Coastal Ecosystem of the Karnataka State, India II - Beaches. Karnataka Association for the Advancement of Science, Bangalore, India.

Sato A., Barcellos G. B. S., Riedel E. C., Carneiro J. A., Carlini C. R., Esquibel M. A. 1993. The presence of concanavalin A and canatoxin in Canavalia ensiformis DC. tissue culture. Pl. Cell Rep. 12: 233-236.

SeEna S., Sridhar K. R. 2004. Endophytic fungal diversity of 2 sand dune wild legumes from the southwest coast of India. Can. J. Microbiol. 50: 1015-1021.

SeEna S., Sridhar K. R. 2006. Nutritional and microbiological features of little known legumes, Canavalia cathartica Thouars and C. maritima Thouars of the southwest coast of India. Current Science 90: 1638-1650.

SRIDHAR K. R. 2009. Bioresources of coastal sand dunes - Are they neglected? In: Coastal Environments: Problems and Perspectives. (Jayappa K. S. \& Narayana A. C., Eds), pp. 53-76, IK International Publishing House Pvt. Ltd., New Delhi, India.

Sridhar K. R., Bhagya B. 2007. Coastal sand dune vegetation: a potential source of food, fodder and pharmaceuticals. Livestock Res. Rural Develop. 19: Article \# 84, http://www.cipav.org. $\mathrm{co} / \mathrm{lrrd} / \mathrm{lrrd} 19 / 6 /$ srid19084.htm

SRIDHAR K. R., SEenA S. 2006. Nutritional and antinutritional significance of four unconventional legumes of the genus Canavalia - A comparative study. Food Chem. 99: 267-288.

Straub P. F., Debra M., Gallagher J. L. 1988. Tissue culture and long term regeneration of Phragmites australis (Cav.) Trin. ex Steud. Plant Cell, Tiss. Org. Cult. 15: 73-78.

Vanisree M., Lee C. -Y., Lo S. -F., Nalawade S. M., Lin C. Y., Tsay H. -S. 2004. Studies on the production of some important secondary metabolites from medicinal plants by plant tissue cultures. Bot. Bull. Acad. Sinica 45: 1-22. 